\title{
Europejskie koncepcje samorządu terytorialnego
}

\section{$\mathbf{S}$} amorząd terytorialny jest immanentnym elementem współczesnego państwa demokratycznego, w którym zdecentralizowane wykonywanie zadań publicznych należy do podstawowego kanonu myślenia politycznego ${ }^{1}$. Określenie miejsca samorządu terytorialnego w strukturze szeroko rozumianego demokratycznego państwa prawnego ${ }^{2}$ wymaga dokonania pogłębionej analizy konkretnych rozwiązań ustrojowych oraz relacji zachodzących między samorządem a władzą państwową. W ujęciu prawnym bowiem samorząd terytorialny występuje w roli „pośredniej administracji państwowej”, a więc takiej, która nie jest pełniona przez bezpośrednie organy państwowe, lecz przez odrębne od państwa podmioty zdolne do działań prawnych, administrujące zadaniami państwowymi $^{3}$. Władza samorządowa jest więc postacią władzy publicznej. Jest zatem instytucją społeczno-polityczną, która posiada prawem ustalony zakres kompetencji do zawiadywania własnymi sprawami ${ }^{4}$. Sprawowana jest przez samą wspólnotę samorządową lub wyłonione przez nią instytucje w imię interesu publicznego. Nie jest jednak władzą suwerenną. Jej konstytutywnym atrybutem jest samodzielność (autonomia lokalna), która jednak jest ograniczona, co oznacza, że nie wszystkie dziedziny życia społecznego mieszczą się w jej zakresie działania (to państwo określa granice spraw lokalnych) oraz podlega obowiązkowi przestrzegania regulacji stanowionych przez państwo, co znajduje wyraz $\mathrm{w}$ instytucji nadzoru państwowego nad samorządem terytorialnym ${ }^{5}$.

Proces restytucji samorządu terytorialnego w krajach Europy Środkowo-Wschodniej zapoczątkowany w latach dziewięćdziesiątych ubiegłego wieku staje się bardziej zrozumiały, gdy dokonamy porównań o charakterze historyczno-politycznym i teoretycznym z procesem, jaki ukształtował współczesne ustroje samorządu w państwach europejskich. Europejskie koncepcje usytuowania samorządu terytorialnego w państwie różnią się w znacznym stopniu, nie tylko pod względem strukturalno-organizacyjnym, ale także zakresem centralizacji lub decentralizacji władzy. Państwo, poczynając od starożytności miało najczęściej postać scentralizowaną. Istota centralizacji, najogólniej rzecz ujmując, to skupienie, zjednoczenie, koncentracja zadań i kompetencji (a więc władzy) w jednym ośrodku decyzyjnym, w przypadku państwa w organach centralnych. Decentralizacja jest wynikiem procesów myślowych, dążeń

\footnotetext{
${ }^{1}$ M. Kulesza, Wprowadzenie, w: Samorzad terytorialny, Warszawa 1995, s. 14.

${ }^{2}$ Zob. M. Kotulski, Samorząd terytorialnyjako instytucja realizująca zasadę demokratycznego państwa prawnego, w: Samorzqd terytorialny III Rzeczypospolitej. Dziesięć lat doświadczén, red. S. Michałowski, Lublin 2002, s. 41-52; F. S. Schnapp, Samorzad jako element politycznego porzqdku państwowego, „Samorząd Terytorialny” 1991, nr 7-8, s. 3 i 9.

${ }^{3}$ B. Dolnicki, Prawnoustrojowe ramy polityki lokalnej, w: Polityka lokalna. Właściwości, determinanty, podmioty, red. E. Ganowicz, L. Rubisz, Toruń 2008, s. 66.

${ }^{4}$ J. Pokładecki, Systemowe znaczenie demokracji na poziomie lokalnym w Polsce, w: Polska demokracja. Koncepcje, płaszczyzny, instytucje, red. S. Wróbel, Toruń 2008, s. 289.

${ }^{5}$ A. Antoszewski, Istota wtadzy samorzadowej, w: Polityka lokalna ..., op. cit., s. 45-48, 58-62.
} 
politycznych, wypływających z procesów rozwoju cywilizacji ludzkiej. Jej początek określa się na przełom XVIII-XIX wieku. Wówczas to ukształtowała się koncepcja państwa zdecentralizowanego, którego istota polega na procesie przekazywania przez ośrodki władzy centralnej zadań i kompetencji strukturom niższego szczebla ${ }^{6}$. We współczesnym świecie decentralizacja struktur państwowych jest zjawiskiem powszechnym. W 95\% państw społeczeństw demokratycznych występują wybieralne organy władcze na poziomie subnarodowym, posiadające różny stopień autonomii ${ }^{7}$. Decentralizację administracji publicznej można więc uznać za podstawowy mechanizm demokratyzacji państwa. Należy jednak pamiętać, że decentralizacja (tak samo jak centralizacja) we współczesnych warunkach jest zjawiskiem złożonym, szczególnie z powodu swojej wielowymiarowości. Jak stwierdza Ch. Pickvance zdecentralizowane systemy rzadzenia maja tyle samo wad co systemy scentralizowane ${ }^{8}$.

W praktyce zachodzących w XIX w. procesów demokratycznych w Europie, podstawową, często prawie wyłączną, formą decentralizacji był samorząd, nade wszystko samorząd terytorialny. Podobne zjawisko o jakim wspomniano wyżej, zaistniało w latach dziewięćdziesiątych XX w. przy transformacji państw „realnego socjalizmu”, z „systemu jednolitej władzy państwowej”, w państwa demokratyczne. W tych warunkach rozwój samorządu terytorialnego pozostawał i pozostaje w silnym związku z procesami politycznymi zachodzącymi w danym kraju, odzwierciedlającymi się w dokonywanych zmianach ustrojowych i funkcjonowaniu struktury państwowej. Samorząd terytorialny ma więc nie tylko charakter administracyjny, lecz jest zjawiskiem politycznym. Może należycie funkcjonować tylko w warunkach ustroju demokratycznego ${ }^{9}$. Trzeba też pamiętać o tym, że pozycja samorządu w państwie demokratycznym może się zmieniać, w zależności, czy władzę w państwie sprawują partie zainteresowane decentralizacją, czy też preferujące centralizację ${ }^{10}$.

Rozwój nowożytnego samorządu terytorialnego w krajach europejskich XIX i XX w. następował w zależności od szczególnych uwarunkowań społeczno-politycznych oraz idei i doktryn filozoficznych. Stąd wielość i zróżnicowanie konkretnych rozwiązań ustrojowych dotyczących samorządu terytorialnego w poszczególnych państwach. Z tej różnorodności można jednak wyodrębnić pewne nurty, które odegrały mniejszą lub większa rolę w tworzeniu i rozwoju europejskich struktur samorządu terytorialnego.

Instytucja samorządu terytorialnego jako podstawowa forma decentralizacji administracji (co było typowe dla kontynentu europejskiego), nie wyczerpuje jednak jego możliwych wariantów zaistnienia. Samorządowi terytorialnemu można nadać także szersze znaczenie - traktując go jako wszystkie postacie udziału obywateli w wykonywaniu funkcji administracyjnych $w$ ramach zarzadu terytorialnego, także tam gdzie nie było centralizacji ${ }^{11}$. W takiej sytuacji samorząd terytorialny był przejawem ,niecentralizacji”, ${ }^{2}$. Było tak na przełomie XVIII i XIX w. w Anglii gdzie, przy braku monarchii absolutnej z charakterystycznym dla niej centralizmem, samorząd był archaiczny i opierał się na rozwiązaniach z czasów średniowiecza. Kluczową formą tego samorządu był samorząd miejski. Poza miastami samorząd

\footnotetext{
${ }^{6}$ H. Izdebski, Historia administracji, Warszawa 1997, s. 138.

${ }^{7}$ B. Gąciarz, Instytucjonalizacja samorzqdności. Aktorzy i efekty, Warszawa 2004, s. 81.

${ }^{8}$ Ch. Pickvance, Decentralizacja i demokracja w Europie Wschodniej. Podejście sceptyczne, ,Samorząd Terytorialny” 1991, nr 9, s. 26. Zob. też B. Gąciarz, Instytucjonalizacja ..., op. cit., s. 80-87; J. Elander, Między centralizmem a lokalnościq, „Samorząd Terytorialny” 1996, nr 9, s. 7-24.

${ }^{9}$ H. Izdebski, Samorzad terytorialny. Podstawy ustroju i działalności, Warszawa 2008, s. 18.

${ }^{10}$ A. Antoszewski, Istota wtadzy..., op. cit., s. 61.

${ }^{11}$ H. Izdebski, Historia ..., op. cit., s. 43-44.

12 Ibidem, s. 44.
} 
terytorialny opierał się na przekazywaniu zarządu lokalnego, w ręce znaczniejszych rodów szlacheckich poszczególnych hrabstw (sędziowie pokoju) $)^{13}$.

Taka struktura władzy lokalnej musiała ulec modernizacji dostosowującej ją do warunków nowoczesnego państwa industrialnego. Proces ten ujęto w dwie zasadnicze reformy samorządowe (w 1835 r. w miastach i w 1888 r. w hrabstwach). Wprowadzono lokalne władze pochodzące z wyborów (rady) i oddzielono je od wymiaru sprawiedliwości. Przeniesiono znaczną część kompetencji hrabstw do okręgów (dystryktów), w których w 1894 roku powołano rady okręgowe i uregulowano status parafii. Istotnym elementem przyjętych rozwiązań prawnych były miasta, które ze względu na wielkość (powyżej 50 tys.) mogły zostać wyłączone z okręgów i tym samym uzyskały własne zadania i kompetencje ${ }^{14}$. Ten okres porządkowania relacji samorząd-państwo i budowania w miarę zespolonego systemu samorządu lokalnego zamyka ustawa Local Government Act z 1929 roku $^{15}$.

Obecnie obowiązujące rozwiązania ustrojowe w Anglii są efektem działań modernizujących administrację lokalną, dokonanych w latach siedemdziesiątych i następnych ubiegłego wieku. W szczególności istotne dla samorządu angielskiego zmiany zaszły w latach 1985 i 1996. W latach osiemdziesiątych XX w. wyraźnie uwidoczniły się tendencje centralistyczne, stąd działania w kierunku wzrostu nadzoru, szczególnie finansowego nad samorządem terytorialnym ${ }^{16}$.

Samorząd angielski a w ślad za tym na obszarach objętych strukturą państwową Wielkiej Brytanii (Szkocja, Walia i Irlandia Północna), czy historycznie poddanych presji imperialnej (Irlandia), cechuje pewna odmienność od rozwiązań obowiązujących na kontynencie. Pojęcie samorząd terytorialny ma nieco odmienne znaczenie niż w innych państwach i jest skoncentrowane na instytucjach władz lokalnych ${ }^{17}$. Ukształtowany w warunkach ,niecentralizacji”, samorząd terytorialny ma silną tradycję i działa w oparciu o historycznie ukształtowane jednostki podziału administracyjnego. Mimo to jest instytucją polityczną, a nie tylko administracyjną, ponieważ spełnia rolę podobną do parlamentu, lecz na poziomie lokalnym. Zakres funkcji dla poszczególnych struktur został określony na podstawie enumeracji pozytywnej, a nie na zasadzie domniemania, jak w większości krajów europejskich. Należy to uznać za pewną sprzeczność, zważywszy na genezę wynikającą z ,niecentralizacji”. Dopiero Local Government Act z 2000 roku przyznał zarządom lokalnym nowe uprawnienia do środowiskowego społecznego i ekonomicznego dobrobytu ${ }^{18}$.

\footnotetext{
13 J. Supernat, W Anglii, w: Samorzq̨d terytorialny i administracja w wybranych krajach. Gmina w państwach Europy Zachodniej, red. J. Jeżewski, Wrocław 1999, s. 20.

${ }^{14}$ H. Izdebski, M. Kulesza, Administracja publiczna. Zagadnienia ogólne, Warszawa 1998, s. 34-35; S. Wójcik, Samorzad terytorialny w Polsce w XX w. Myśl samorzqdowa, historia i współczesność, Lublin 1999, s. 57.

15 E. J. Nowacka, Polski samorzad terytorialny, Warszawa 2006, s. 179-181.

${ }^{16}$ Ibidem.

${ }^{17}$ Za autora pojęcia samorząd uznaje się niemieckiego prawnika H. R. Gneista, który posłużył się metodą przeciwstawienia terminowi „Staatsverwaltung”, co znaczy administracja państwowa i terminowi „Selbstverwaltung”, thumacząc na język polski jako samoadministracja, co uznaje się jako „,samorząd”. W języku angielskim odpowiednikiem terminu samorząd są ,self-government” lub „local government” i oznaczają instytucję lokalną lub administrację terenową, które nie zawsze mają charakter samorządowy. Pojęcie to utożsamiane jest z dekoncentracją administracji publicznej. Zob. S. Wykrętowicz, Samorzad jako wyraz demokracji obywatelskiej, w: Samorzqd w Polsce. Istota, formy, zadania, red. S. Wykrętowicz, Poznań 2008, s. 72.

18 J. Wojnicki, Samorzady lokalne w Polsce i Europie, Pułtusk 2008, s. 183; L. Rajca, Samorzqd terytorialny w Zjednoczonym Królestwie Wielkiej Brytanii i Pótnocnej Irlandii, w: Samorzqd terytorialny w Europie Zachodniej, red. L. Rajca, Warszawa 2010, s. 286.
} 
Do niedawna odmiennością był też brak klasycznego podziału na organy uchwałodawcze i wykonawcze. Pewne zmiany w tym względzie zostały zaproponowane dopiero przez rząd laburzystów w dokumencie konsultacyjnym Modernizacja zarzqdu lokalnego: Demokracja lokalna i przywództwo wspólnoty ${ }^{19}$. Czego efektem jest możliwość (po konsultacji z mieszkańcami) wyboru organu wykonawczego w trybie wyborów powszechnych i wprowadzenie zmodyfikowanego systemu komitetowego ${ }^{20}$. Rady działają w systemie plenarnym oraz komisji (komitetów), ale ich funkcje zostały w pewnych sprawach ograniczone. Nadal istotną rolę odgrywają urzędnicy, ponieważ wraz z radnymi mogą kształtować określone decyzje. Najnowsze regulacje podkreślają znaczenie urzędniczych szefów administracji hrabstwa czy dystryktu. Przewodniczący rady w dystrykcie lub w hrabstwie, pełni funkcje głównie ceremonialne, organizacyjne i reprezentacyjne ${ }^{21}$. Samorząd angielski posiada szeroki zakres niezależności od władz centralnych w ramach przyznanych mu kompetencji. Ograniczenia samodzielności należy doszukiwać się przede wszystkim w niewystarczających zasobach finansowych. Jest to zjawisko występujące również w wielu krajach europejskich.

W podobnych do angielskich warunkach ,niecentralizacji” jednakże pod nadzorem przedstawicieli władz centralnych, kształtował się samorząd w Szwecji ${ }^{22}$.

Podstawowe znaczenie dla rozwoju samorządu terytorialnego jako formy decentralizacji miała na kontynencie europejskim Wielka Rewolucja Francuska. W pierwszym okresie walk rewolucyjnych przeciwko feudalizmowi tworzono nowe władze lokalne o charakterze w pełni samorządowym. Towarzyszyła temu odwołująca się do filozofii praw natury i liberalizmu politycznego koncepcja ,wolnej gminy”, jako czwartej władzy (po ustawodawczej, wykonawczej i sądowniczej). W analogii do prawa naturalnego jednostki do wolności uważano, że takie prawo ma też gmina jako twór naturalny, a tym samym pierwotny w stosunku do państwa. Oparta na koncepcji „,wolnej gminy” zasada „pouvoir municipal” niezależnej od państwa władzy lokalnej, będącej wobec niego w opozycji została wpisana do konstytucji ${ }^{23}$. Szybko jednak, co było spowodowane powstającym chaosem w administracji, trudną sytuacją zewnętrzną i wewnętrzną, jak również brakiem przyzwyczajenia większości mieszkańców Francji do tej formy zarządu lokalnego, (samodzielność wybieralnych przez ludność, przy dużych ograniczeniach cenzusowych, organów władzy lokalnej) została poddana ograniczeniom $^{24}$. Ostateczny cios możliwościom realizacji koncepcji „,wolnej gminy”, co potem wpływało na rozwój samorządu terytorialnego we Francji, zadał Napoleon Bonaparte, wprowadzając ustawą z 17 lutego 1800 roku system scentralizowany, w którym władze lokalne (municypalne, okręgowe i departamentalne) dysponowały jedynie władzą fasadową ${ }^{25}$.

Kolejne próby wykorzystania koncepcji ,wolnej gminy” w praktyce politycznej pozostawały także w związku z działaniami rewolucyjnymi i miały przede wszystkim wymiar ideologiczny. W ten sposób ,wolna gmina” została wpisana do konstytucji belgijskiej w 1831 roku, co jednak nie oznaczało realizacji tej koncepcji, o czym świadczyły, szczególnie narastające

\footnotetext{
${ }^{19}$ Ibidem, s. 307.

${ }^{20}$ Ibidem.

${ }^{21}$ H. Izdebski, Samorzad terytorialny..., op. cit., s. 45; A. Piasecki, Samorzą terytorialny i wspólnoty lokalne, Warszawa 2009, s. 68-69.

${ }^{22}$ M. Popławski, Samorzą terytorialny w Królestwie Szwecji, Toruń 2006; H. Izdebski, M. Kulesza, Administracja publiczna..., op. cit., s. 54-55.

${ }^{23}$ K. Grzybowski, Historia doktryn politycznych i prawnych, Warszawa 1967, s. 349-355; H. Kwiatkowski, Mozaika europejska (1), „Rada Narodowa” 1989, nr 34, s. 6; S. Wójcik, Samorzqd terytorialny..., op. cit., s. 62.

${ }^{24}$ H. Izdebski, Historia administracji..., op. cit., s. 132.

25 J. Tulard, Napoleon - mit zbawcy, Warszawa 2003, s. 128.
} 
tendencje centralistyczne ${ }^{26}$. Przejściowo w okresie Wiosny Ludów „konstytucja frankfurcka” z 1848 roku oraz ustawa austriacka z 1849 roku przyznały gminom prawo zasadnicze, tj. prawo własne samorządu, stanowiące o pozycji prawnej samorządu, według których wolna gmina ma być podstawa wolnego państwa ${ }^{27}$.

Pomimo braku możliwości realizacji ustrojowej, koncepcja „wolnej gminy” nabrała mimo wszystko szczególnego znaczenia ideologicznego, co znalazło wyraz w tzw. naturalistycznej teorii samorządu terytorialnego, której elementy po dziś dzień wykorzystuje się w różnorakich interpretacjach socjologicznych czy politologicznych dotyczących samorządu terytorialnego, szczególnie w warstwie aksjologicznej (do czego wrócę w dalszych rozważaniach).

Napoleońska organizacja administracyjna stanowiła wzór nie tylko konsekwentnego centralizmu biurokratycznego, lecz również zespolenia i jednoosobowości ${ }^{28}$. W ten scentralizowany model państwa z czasem zaczęto, w ramach procesów demokratyzacyjnych, stopniowo wprowadzać samorząd terytorialny. Zmiany te, dokonujące się głównie w XIX w. były niewielkie w porównaniu z innymi państwami europejskimi. Gminom samorządowy charakter, ale pod silnym nadzorem rządowym, ostatecznie nadała ustawa z 1884 roku. Od 1871 roku za jednostki samorządu terytorialnego uznano departamenty, ale samorząd ten był bardzo słaby, pozbawiony własnego aparatu wykonawczego. W 1941 roku zlikwidowano pochodzące $\mathrm{z}$ okresu rewolucji rady ${ }^{29} \mathrm{w}$ okręgach (arrondissement), tworząc $\mathrm{z}$ tych jednostek formę terytorialnej administracji rządowej.

Stan ten poddawany kolejnym, niewiele znaczącym reformom (lata 1946, 1958, 1969, 1976), uległ dopiero znaczącej zmianie jakościowej w 1982 roku. Wdrażanie nowych rozwiązań trwało do 1988 roku, co miało zapewnić powodzenie reform oraz zyskanie akceptacji społeczeństwa francuskiego ${ }^{30}$. Istota nowej regulacji prawnej została zapisana w kilku aktach prawnych $^{31}$, gdzie określono koncepcje zmian o charakterze ustrojowo-terytorialnym, zmiany w podziale kompetencji organów państwa, nadzoru i kontroli oraz środków do ich realizacji. W strukturze podziału terytorialnego najważniejsza zmiana dotyczyła nadania regionom uprawnień samorządowych, poprzez ustanowienie rad pochodzących z wyborów powszechnych i bezpośrednich. Wyposażono je też w prawo do określania polityki rozwoju na podstawie własnej strategii. Wcześniej prawa takie uzyskały departamenty i gminy. Na wszystkich trzech poziomach rady wybierają swoich przewodniczących, pełniących funkcje monokratycznych organów wykonawczych. Znaczącym przejawem ograniczania roli państwa była zmiana pozycji i uprawnień wykonawczych prefekta jako głównego reprezentanta państwa na poziomie departamentu i regionu.

Wprowadzenie samorządu terytorialnego we Francji jak zauważa H. Izdebski odbyło się bez precyzyjnego zdefiniowania samego pojęcia. Dlatego zamiast o „samorządzie” mówi się o ,administracji zdecentralizowanej” lub jak to stanowi wspomniana ustawa z 1982 roku

\footnotetext{
${ }^{26}$ J. Boć, Autonomia gminy (samorząd gminny) w Belgii, ,Samorząd Terytorialny” 1992, nr 3, s. $27-33$.

${ }^{27}$ S. Wójcik, Samorząd terytorialny..., op. cit., s. 73.

${ }^{28}$ H. Izdebski, M. Kulesza, Administracja publiczna..., op. cit., s. 38.

${ }^{29}$ Ibidem, s. 41.

${ }^{30}$ Reforma była realizowana metodą tzw. „małych kroków’, aby uzyskać jak największą aprobatę społeczną. Wcześniejsze próby, np. w kwietniu 1969 roku przeprowadzono referendum dotyczące usamorządowienia regionu, zakończyły się fiaskiem.

${ }^{31}$ Do najważniejszych zaliczyć należy: ustawę z dnia 2 marca 1982 roku dotyczącą praw i wolności gmin, departamentów i regionów; ustawę z dnia 7 stycznia 1983 roku dotyczącą podziału kompetencji między gminy, departamenty, regiony i państwo.
} 
o prawach $i$ wolnościach gmin, departamentów i regionów ${ }^{32}$. Specyfika administracji terytorialnej w systemie francuskim polega na dualizmie i należy ją rozpatrywać w dwóch wymiarach: decentralizacji i dekoncentracji. Wymiar decentralizacji wskazuje na terytorialny charakter interesów lokalnych, samodzielnie realizowanych przez społeczności lokalne, będące - osobami prawa publicznego, a więc gminy, departamenty i regiony. Należy jednak zwrócić uwagę, że liczba gmin (o charakterze jednorodnym) jest bardzo duża, co ogranicza ich samodzielność ${ }^{33}$. W wymiarze dekoncentracji poszczególne struktury terytorialne, traktowane są jako jednostki podziału administracyjnego państwa, wykonujące określone ustawowo kompetencje, które są zarazem hierarchicznie podporządkowane administracji rządowej ${ }^{34}$. Stąd pomimo wprowadzonych zmian, zwłaszcza po znowelizowaniu Konstytucji V Republiki w 2003 roku, gdzie art. 1 stanowi się, że Republika zorganizowana jest w sposób zdecentralizowany z zachowaniem jej jedności i niepodzielności ${ }^{35}$. System francuski nadal wykazuje znaczne cechy centralizacji, bowiem jednostkom samorządu terytorialnego pozostawiono stosunkowo ograniczoną sferę zadań oraz ograniczoną samodzielność finansową. W ślad za tym idzie tendencja do budowania różnych form współpracy międzygminnej ${ }^{36}$.

Pośrednią konsekwencją Wielkiej Rewolucji Francuskiej było ukształtowanie się pruskiej koncepcji samorządu terytorialnego, która zakłada, że instytucja ta może istnieć wyłącznie z woli państwa i spełniać tylko powierzone jej przez państwo zadania ${ }^{37}$.

Punktem wyjścia do przyjętych w Prusach działań decentralizacyjnych była reforma miejska barona K. von Steina z 1808 roku. Wprowadzenie nowego samorządu miejskiego nie było przejawem dążeń wolnościowych mieszczan, ale nastąpiło w trybie edyktu królewskiego, a więc przejawu woli absolutnego monarchy. Było to działanie zainicjowane odgórnie dla umocnienia państwa, a nie usankcjonowania praw mieszkańców. Celem steinowskiej reformy nie była wolna gmina, ale obywatel państwa, który angażując się do dobra publicznego może uzyskać prawa polityczne. Aby takie cele osiagać konieczna była decentralizacja ${ }^{38}$.

Rozwiązania francuskie i pruskie już od zarania mocno się różniły. Jak już wcześniej wskazano model francuski (ponapoleoński) tolerował gminę z konieczności, traktując jąjako strukturę do wykonywania administracji rządowej, model pruski zaś był nastawiony na cel polityczny i angażowanie obywateli do współpracy z administracją państwową. Różnice dotyczyły również rozwiązań o charakterze ustrojowym ${ }^{39}$. Ważną innowacją wprowadzenia pruskiej ordynacji miejskiej była jej powszechność, polegająca na systematyzacji prawa miejskiego. Rola miast ukształtowana w warunkach feudalnych nie ulegała zmianie. Pozostawały one częścią państwa, ale już jako korporacje z ograniczonymi prawami administracyjnymi i zdolnościami do działania na własną odpowiedzialność. Strukturami decyzyjnymi były rady

${ }^{32}$ H. Izdebski, Samorzad terytorialny..., op. cit., s. 47.

${ }^{33}$ K. Chorąży, Zagadnienia ustroju lokalnego Francji, Lublin 1998, s. 36.

${ }^{34}$ J. Jeżewski, We Francji..., op. cit., s. 153.

${ }^{35}$ M. Kasiński, Monizm i pluralizm władzy lokalnej. Studium prawno-polityczne, Łódź 2009, s. 206.

${ }^{36}$ A. Poplewska, Wspótpraca międzygminna we Francji, „Samorząd Terytorialny” 2002, nr 1-2; M. Ofierska, Nowy model wspótpracy międzygminnej we Francji (na tle reformy z 1999 roku), „Samorząd Terytorialny” 2003, nr $1-2$, s. 127 i n.

${ }^{37}$ J. Panejko, Geneza i podstawy samorzqdu europejskiego, Wilno 1934, wyd. II, s. 42-44.

${ }^{38}$ M. Miemiec, Gmina w systemie administracji publicznej Republiki Federalnej Niemiec, Kolonia Limited 2007, s. 13.

${ }^{39}$ We Francji dominował monokratyczny organ wykonawczy, a w klasycznym modelu pruskim dominowały organy kolegialne. 
miejskie wybierane przez mieszkańców, będących obywatelami miasta. Obywatelstwo było oparte na cenzusie posiadania ${ }^{40}$.

Po Kongresie Wiedeńskim (w 1815 roku) nastąpiła w Prusach reakcja absolutyzmu, co zahamowało proces rozwoju samorządu terytorialnego, który jeżeli się pojawiał, to jeszcze w ramach podziałów stanowych (samorząd powiatowy i prowincjonalny). Teoretyczne sformułowanie zasad samorządu terytorialnego współistniejącego z administracją typu biurokratycznego zostało dokonane przez H. R. Gneista dopiero w drugiej połowie XIX w. Jego zdaniem administracja samorządowa musiała spełniać inne zadania niż administracja scentralizowana, jednak musiała z nią współpracować, co miało zapewnić pozostawienie organów administracji biurokratycznej na czele organów wykonawczych samorządu. Założenia te stały się podstawą dla reform instytucji samorządu terytorialnego, które wprowadzono w Prusach w latach 1872-1875 . Opór ziemiaństwa opóźnił w Prusach znacznie, bo aż do 1891 roku, wprowadzenie samorządu na wsi.

W efekcie w Prusach, a także na innych terenach Cesarstwa Niemieckiego, powstała charakterystyczna dualistyczna konstrukcja samorządu terytorialnego zakładająca daleko idące współwystępowanie w terenie organów reprezentujących władzę centralną i organów reprezentujących obywateli danej jednostki terytorialnej (samorządu terytorialnego). Podział kompetencyjny preferował jednak administrację państwową, której przysługiwały uprawnienia nadzorcze wobec samorządu. Ta konstrukcja, mimo trudności z praktyczną realizacją niektórych ich elementów, stanowiła podstawę budowania administracji terytorialnej w Niemczech i w Austrii, a także wywarła duży wpływ na kształtowanie się samorządu terytorialnego w całej Europie ${ }^{42}$. Znalazła ona też swoje odzwierciedlenie w tzw. państwowej teorii samorządu.

Rozwój i upowszechnianie struktur samorządu terytorialnego w Europie w XIX w. spowodował, że stał się on przedmiotem refleksji naukowej. Budowane na tym gruncie koncepcje nie tylko służyły objaśnianiu samego zjawiska samorządu terytorialnego, ale były też intelektualną i ideologiczną podstawą przeprowadzanych reform władzy lokalnej (np. koncepcje H. R. Gneista). Główne spory dotyczyły istoty i pojęcia samorządu terytorialnego, a nade wszystko kwestii usytuowania jego podstawowej jednostki, czyli gminy, w stosunku do państwa. Efektem tych kontrowersji było ukształtowanie się, o czym już wspomniano, dwóch nurtów teoretycznych: naturalistycznego i państwowego.

Naturalistyczna teoria samorządu łączyła zrodzoną w czasie Wielkiej Rewolucji Francuskiej koncepcję „wolnej gminy” z doktryną prawa naturalnego oraz myślą liberalną ${ }^{43}$. Jej zwolennikami byli m.in. A. Tocqueville ${ }^{44}$, M. de Argenoas, J. Turgot, A. R. J. Thouret, C. Arenit von Rotteck ${ }^{45}$. W tej teorii uznano, że gmina jest pierwotną wobec państwa formą organizacji społeczeństwa, a więc jej prawa kształtują się na wzór praw naturalnych. Gmina więc jest wspólnotą terytorialną całkowicie niezależną od państwa i funkcjonuje niezależnie od jego woli, posiada przyrodzone prawo do samodzielności, czyli do samorządu, które państwo powinno respektować i chronić.

\footnotetext{
${ }^{40}$ M. Miemiec, Gmina w systemie administracji..., op. cit., s. 14.

${ }^{41}$ H. Izdebski, Historia administracji..., op. cit., s. 146-147.

${ }^{42}$ H. Izdebski, M. Kulesza, Administracja publiczna..., op. cit., s. 50-51.

${ }^{43}$ K. Sidorkiewicz, Idea samorzqdu w myśli liberalnej, w: Samorząd terytorialny w krajach Unii Europejskiej, red. K. Gomółka, Elbląg 2007, s. 7-16.

${ }^{44}$ A. de Tocqueville, O demokracji w Ameryce, Warszawa 1976, s. 71.

45 J. Panejko, Geneza i podstawy..., op. cit., s. 79-80.
} 
Przeciwieństwem teorii naturalistycznej jest teoria państwowa samorządu, ukształtowana w II połowie XIX w. w oparciu o pruską i francuską praktykę ustrojową oraz pod wpływem konstytucjonalizmu prawniczego i narastającego interwencjonizmu państwowego. Jej zwolennikami byli: K. von Stein, H. R. Gneist, O. von Gierke, O. Mayer, P. Laband, G. Jelinek i inni $^{46}$. W teorii tej zakłada się suwerenność państwa, wykonującego władzę przez własne organy. Państwo to może jednak część władztwa przekazać społeczności lokalnej jako odrębnemu podmiotowi. $W$ ten sposób ukształtowany samorząd ma charakter państwowy, a więc istnieje z woli państwa, realizując zadanie przekazane przez państwo. Samorząd mimo swojej samodzielności jest częścią państwa, ponieważ wykonuje tylko te zadania (mogą to być własne lub poruczone), które państwo przekazało lub, z których zrezygnowało na rzecz samorządu. Stąd samorząd określa się jako zdecentralizowaną administrację państwową. Koncepcję tę można określić mianem funkcjonalnej, ponieważ dostrzega ona sens istnienia samorządu tylko o tyle, o ile przyczynia się on do sprawniejszego i bardziej efektywnego funkcjonowania państwa.

Przeobrażenia polityczne i ustrojowe zachodzące w XX w. zweryfikowały pozytywnie zasadność państwowej teorii samorządu terytorialnego, szczególnie w jej zliberalizowanej postaci. Dokooptowano jednak do niej wywodzącą się z prawa natury zasadę pomocniczości (subsydiarności $^{47}$, zgodnie z którą niesprawiedliwościa, szkoda społeczna i zakłóceniem ustroju jest zabieranie mniejszym i niższym społecznościom tych zadań, które moga spetniać $i$ przekazanie ich społecznościom większym $i$ wyższym ${ }^{48}$. Procesy integracyjne w Europie przyczyniły się do określenia w Europejskiej Karcie Samorządu Terytorialnego (Lokalnego) z 1985 roku standardów rozwiązań prawnych dotyczących samorządu terytorialnego. Może to być punktem wyjścia do budowania nowej, uniwersalistycznej teorii samorządu terytorialnego $^{49}$.

\section{Bibliografia}

Antoszewski A., Istota władzy samorzqdowej, w: Polityka lokalna. Właściwości, determinanty, podmioty, red. E. Ganowicz, L. Rubisz, Toruń 2008.

Chorąży K., Zagadnienia ustroju Francji, Lublin 1998.

Boć J., Autonomia gminy (samorzad gminny) w Belgii, „Samorząd Terytorialny” 1992, nr 3.

Dobosz P., Uniwersalistyczna teoria samorzadu terytorialnego. (Teoria ponadpaństwowych determinant modelu samorzadu terytorialnego), w: Prawo do dobrej administracji, red. Z. Cieślak, Z. Niewiadomski, Warszawa 2003.

Dolnicki B., Prawnoustrojowe ramy polityki lokalnej, w: Polityka lokalna. Właściwości, determinanty, podmioty, red. E. Ganowicz, L. Rubisz, Toruń 2008.

Elander J., Między centralizmem a lokalnościa, „Samorząd Terytorialny” 1996, nr 9.

Gąciarz B., Instytucjonalizacja samorzadności. Aktorzy i efekty, Warszawa 2004.

\footnotetext{
${ }^{46}$ S. Wójcik, Polityczne i teoretyczne aspekty decentralizacji administracji, w: Samorząd gminny w Polsce. Doświadczenia i perspektywy, red. B. Nawrot, J. Pokładecki, Poznań 1999, s. 26.

${ }^{47}$ Zob. W. Niecikowski, Czy pomocniczość jest receptq na powstawanie społeczeństwa obywatelskiego?, „Samorząd Terytorialny" 1999, nr 1-2, s. 3-11; A. Szpor, Państwo a subsydiarność jako zasada prawna w UE i Polsce, „Samorząd Terytorialny” 2001, nr 1-2, s. 3-19.

${ }^{48}$ Dokumenty nauki społecznej Kościoła, red. M. Radwan, L. Dyczewski, A. Stanowski, Lublin 1994, cz. 1, pkt 79-80, s. 85-86.

${ }^{49}$ Zob. P. Dobosz, Uniwersalistyczna teoria samorzadu terytorialnego. (Teoria ponadpaństwowych determinant modelu samorzadu terytorialnego), w: Prawo do dobrej administracji, red. Z. Cieślak, Z. Niewiadomski, Warszawa 2003, s. 318-334.
} 
Grzybowski K., Historia doktryn politycznych i prawnych, Warszawa 1967.

Izdebski H., Historia administracji, Warszawa 1997.

Izdebski H., Kulesza M., Administracja publiczna. Zagadnienia ogólne, Warszawa 1999.

Izdebski H., Samorzą terytorialny. Podstawy ustroju i działalności, Warszawa 2008.

Kasiński M., Monizm i pluralizm władzy lokalnej, Łódź 2009.

Kulesza M., Samorzad terytorialny, Warszawa 1995.

Miemiec M., Gmina w systemie administracji publicznej Republiki Federalnej Niemiec, Kolonia 2007.

Nowacka E., Polski samorzad terytorialny, Warszawa 2006.

Ofierska M., Nowy model wspótpracy międzygminnej (na tle reformy z 1999 roku), „Samorząd Terytorialny 2003, nr 1-2.

Panejko J., Geneza i podstawy samorzqdu europejskiego, Wilno 1934, II wyd.

Piasecki A. K., Samorzqd terytorialny i wspólnoty lokalne, Warszawa 2009.

Pickvance Ch., Decentralizacja i demokracja w Europie Wschodniej, podejście sceptyczne, „Samorząd Terytorialny" 1991, nr 9.

Polityka lokalna. Właściwości, determinanty, podmioty, red. E. Ganowicz, L. Rubisz, Toruń 2008.

Polska demokracja. Koncepcje, płaszczyzny, instytucje, red. S. Wróbel, Toruń 2008.

Poplewska A., Wspótpraca międzygminna we Francji, „Samorząd Terytorialny” 2002, nr 1-2.

Pokładecki J., Systemowe znaczenie demokracji na poziomie lokalnym w Polsce, w: Polska demokracja. Koncepcje, plaszczyzny, instytucje, red. S. Wróbel, Toruń 2008.

Popławski M., Samorzad terytorialny w Królestwie Szwecji, Toruń 2006.

Samorzad terytorialny $i$ administracja $w$ wybranych krajach. Gmina $w$ państwach Europy Zachodniej, red. J. Jeżewski, Wrocław 1999.

Samorząd w Polsce. Istota, formy, zadania, red. S. Wykrętowicz, Poznań 2008.

Schnapp F., Samorzqd jako element politycznego porzqdku państwowego, „Samorząd Terytorialny” 1991, nr 7-8.

Samorzą terytorialny III RP. Dziesięć lat doświadczeń, red. S. Michałowski, Lublin 2002.

Samorzad terytorialny w Europie Zachodniej, red. L. Rajca, Warszawa 2010.

Sidorkiewicz K., Idea samorzqdu w myśli liberalnej, w : Samorzq̨d terytorialny w krajach Unii Europejskiej, red. K. Gomółka, Elbląg 2007.

Tulard J., Napoleon - mit zbawcy, Warszawa 2003.

Wójcik S., Samorzad terytorialny w Polsce w XX w. Myśl samorzqdowa, historia i współczesność, Lublin 1999.

Wójcik S., Polityczne i teoretyczne aspekty decentralizacji, w: Samorzqd gminny w Polsce. Doświadczenia i perspektywy, red. B. Nawrot, J. Pokładecki, Poznań 1999.

\section{Summary}

Territorial self-government is one of the fundamental institutions of a modern democratic state of law. There are numerous European traditions of self-government that have produced different concepts and, consequently, different theories of territorial self-government. The most important ones include the naturalist, state, and political theories. Each of them shows a different picture of the origin, essence and the scope of legal personality a territorial self-government has, of local communities, the position of the administrative unit of the commune and higher units. Depending on the concept one chooses, political and organizational solutions are differentiated, as are the tasks of territorial self-government units, the competences of its organs and the authority of state organs to exercise control and supervision. On the basis of the solutions adopted in every country, and at a given level of development of the state, the degree of decentralization of power, the degree of autonomy, self-reliance and independence of territorial self-government is determined. 
